\title{
PENGARUH FEE BASED INCOME TERHADAP LABA OPERASIONAL PADA BANK BUMN YANG TERDAFTAR DI BEI
}

\author{
Irawan Budi Prasetyo \\ STIE Malangkucecwara \\ Malang \\ e-mail : irawan@stie-mce.ac.id
}

\begin{abstract}
This study aims to determine the effect of commissions, fees and fees, foreign exchange and other income simultaneously and partially on the operating profit of banks listed on the Indonesia Stock Exchange in the period 2007-2014. This research is a correlational study which aims to determine the relationship and influence of the independent and dependent variables. The object of this research is state-owned banks listed on the Indonesia Stock Exchange for a period of 4 years (2007-2014) whose data have been grouped by purposive sampling. While the analysis tool used is linear regression. The results show that foreign exchange (X2) has a significant and dominant effect on operating profit (Y), which means that an increase in foreign exchange earnings will be followed by an increase in operating profit. Simultaneously, commission, fees and fees, foreign exchange or foreign exchange earnings, other income $(X 1,2,3)$ affect operating profit by $83.2 \%$, and the remaining $16.8 \%$ is influenced by other factors not calculated in this study.
\end{abstract}

\begin{abstract}
ABSTRAK
Penelitian ini bertujuan untuk mengetahui pengaruh komisi, provisi dan fee, valuta asing dan pendapatan lainnya secara simultan dan parsial terhadap laba operasional bank bank yang terdaftar di Bursa Efek Indonesia dalam kurun waktu 2007-2014. Penelitian ini merupakan penelitian korelasional yang bertujuan untuk mengetahui hubungan dan pengaruh variabel bebas dan variabel terikat.Obyek penelitian adalah bank bank BUMN yang terdaftar di Bursa Efek Indonesia dalam kurun waktu 4 tahun (2007 - 2014 ) yang datanya telah di kelompokkan dengan cara purposive sampling. Sedangkan alat analisis yang digunakan adalah regresi linier. Hasil penelitian menunjukkan bahwa valuta asing atau devisa $\left(\mathrm{X}_{2}\right)$ berpengaruh signifikan dan dominan terhadap laba operasional (Y) yang berarti dengan adanya kenaikan pendapatan valuta asing atau devisa akan diikuti oleh peningkatan laba operasional. Secara simultan pendapatan komisi, provisi dan fee, Pendapatan valuta asing atau devisa, pendapatan lainnya (X1,2,3) mempengaruhi laba operasional sebesar 83,2\%, dan sisanya 16,8\% dipengaruhi oleh faktor lain yang tidak dihitung dalam penelitian ini.
\end{abstract}

Kata Kunci : Fee Based Income, Valuta Asing dan Pendapatn lain.

\section{PENDAHULUAN}

Indonesia adalah merupakan negara berkembang sedang giat melaksanankan pembangunan negara dalam semua aspek kehidupan, termasuk di aspek perekonomian. Seiring dengan majunya sistem informasi yang bergerak cepat sesuai perkembangan zaman, pertumbuhan Indonesia pun mengalami peningkatan. Majunya perekonomian di Indonesia ini tidak lepas dari peran masyarakat yang melakukan usaha di bidang perekonomian. Seluruh aktivitas dalam dunia bisnis baik yang besar, menengah maupun kecil tidak pernah lepas dari transaksi keuangan yang akan melibatkan perbankan sebagai perantara terutama dalam 


\section{Buletin Ekonomi}

transaksi keuangan. Perbankan sangat dikenal masyarakat luas, dengan adanya teknologi saat ini dapat memudahkan masyarakat dalam mengetahui sumber informasi mengenai perbankan. Sehingga bisa memicu masyarakat untuk lebih selektif dalam menanamkan dananya pada bank tertentu.

Menurut Undang-Undang No.10 Tahun 1998 tanggal 10 November 1998 tentang perbankan, dapat disimpulkan bahwa usaha perbankan meliputi tiga kegiatan yaitu menghimpun dana, menyalurkan dana dan memberikan jasa bank lainnya. Kegiatan menghimpun dan menyalurkan dana merupakan kegiatan pokok bank sedangkan memberikan jasa bank lainnya hanya kegiatan pendukung. Fee Based income merupakan pendapatan yang diperoleh bank dari pemberian jasa-jasa perbankan seperti transfer, kliring, inkaso, safe deposit box, bank card, bank garansi, letter of credit dan lainnya. Menerima setoran-setoran seperti pembayaran pajak, telepon, listrik, air,dan uang kuliah, melayani pembayaranpembayaran berupa gaji, pembagian dividen, kupon, pemberian hadiah, dan juga transaksi valuta asing dang lain sebagainya. Adapun biaya yang terdapat dalam fee based income antara lain biaya administrasi, biaya kirim, biaya provisi dan komisi, biaya sewa dan biaya iuran. Dalam laporan keuangan bank, fee based income dimasukkan dalam pendapatan operasional lainnya.

Memperoleh laba merupakan tujuan utama dari suatu perusahaan baik sektor perbankan ataupun lembaga keuangan lainnya. Laba yang telah diperoleh bukan saja digunakan untuk membiayai operasi perusahaan, tapi juga digunakan juga untuk ekspansi dimasa yang akan datang.

Penelitian Aprillya, Shella Fitri (2013) mengenai pengaruh fee based income terhadap tingkat Return On Assets. Hasil analisis hipotesis penelitian menunjukkan bahwa fee based income berpengaruh terhadap ROA dimana besarnya pengaruh adalah 65,9\% dan sisanya dipengaruhi oleh faktor lain. Sedangkan penelitian Astri, Nita Nur (2014) tentang pengaruh fee based income terhadap profitabilitas, menunjukkan hasil pengaruh positif fee based income terhadap profitabilitas. Dari penelitian-penelitian terkait tentang fee based income, maka terlihat begitu besarnya pengaruh fee based income terhadap pendapatan industri perbankan di Indonesia. Oleh karena itu, perbankan mulai menggiatkan usaha untuk memperoleh pendapatan bukan hanya dari pendapatan bunga saja, tetapi juga dari pendapatan jasa yang cukup menjanjikan.

Berdasarkan uraian latar belakang permasalahan di atas maka dapat disusun rumusan masalah sebagai berikut: (1) Apakah komisi, provisi dan fee berpengaruh terhadap Laba Operasional pada Bank Umum Milik Negara yang terdaftar di Bursa Efek indonesia (BEI)?; (2) Apakah pendapatan valuta asing berpengaruh terhadap Laba Operasional pada Bank Umum Milik Negara yang terdaftar di Bursa Efek indonesia (BEI)?; (3) Apakah pendapatan lain berpengaruh terhadap terhadap Laba Operasional Bank Umum Milik Negara yang terdaftar di Bursa Efek Indonesia (BEI)?; dan (4) Apakah komisi, provisi, fee, pendapatan valuta asing dan pendapatan lain berpengaruh terhadap Laba Operasional Bank Umum Milik Negara yang terdaftar di Bursa Efek indonesia (BEI) secara simultan?.

Menurut Undang-undang Nomor 10 Tahun 1998 tanggal 10 November 1998 tentang Perbankan bahwa: "Bank adalah badan usaha yang menghimpun dana dari masyarakat dalam bentuk simpanan dan menyalurkannya kepada masyarakat dalam bentuk kredit dan atau dalam bentuk lainnya dalam rangka menigkatkan taraf hidup rakyat banyak". Menurut Kasmir (2012) "Bank merupakan lembaga keuangan yang kegiatan utamanya adalah menghimpun dana dari masyarakat dan menyalurkan kembali kepada masyarakat serta memberikan jasa bank lain”. 


\section{Buletin Ekonomi}

\section{Fungsi Bank}

Bank Umum mempunyai fungsi pokok seperti yang dikemukakan oleh Hasibuan, Malayu (2009) adalah: "Fungsi utama perbankan adalah sebagai penghimpun dan penyalur dana masyarakat." Sedangkan Damawi, Herman (2011) menyatakan fungsi-fungsi yang dilakukan bank umum agar dapat menjalankan perannya yaitu: (1) Menghimpun dana dari tabungan masyarakat, (2) Menyediakan dana untuk dipinjamkan (kredit), (3) Menyediakan jasa lalu lintas pembayaran, (4) Menciptakan uang giral, (5) Menyediakan fasilitas untuk memperlancar perdangan luar negeri, (6) Menyediakan jasa-jasa trusty (wali amanat), dan (7) Menyediakan berbagai jasa yang bersifar "off balance sheet" seperti jasa safety deposit boxes, inkaso, pialang, garansi bank, dan lain-lain."

\section{Jenis-Jenis Bank}

Menurut Kasmir (2012) terdiri dari: (1) Bank Sentral, (2) Bank Umum, dan (3) Bank Perkrediran Rakyat. Fungsi bank tersebut dijelaskan sebagai berikut: (1) Bank Sentral. Bank Sentral di Indonesia dilaksanakan oleh Bank Indonesia dan memegang fungsi sebagai bank sirkulasi, bank to bank, dan lender of the last. Pelayanan yang diberikan oleh Bank Indonesia lebih banyak kepada pihak pemerintah dan dunia perbankan. Tujuan utama Bank Indonesia sebagai Bank Sentral adalah mencapai dan memelihara kestabilan nilai rupiah; (2) Bank Umum. Bank umum merupakan bank yang bertugas melayani seluruh jasa-jasa perbankan dan melayani segenap lapisan masyarakat, baik masyarakat perorangan maupun lembagalembaga lainnya; dan (3) Bank Perkreditan Rakyat. Bank Perkreditan Rakyat (BPR) merupakan bank yang khusus melayani masyarakat kecil di kecamatan dan perdesaan. Bank Perkreditan Rakyat berasal dari Bank Desa, Bank Pasar, Bank Lumbung Desa, Bank Pegawai dan bank lainnya yang kemudian dilebur menjadi Bank Perkreditan Rakyat.

\section{Pendapatan Bank}

Tujuan utama bank melaksanakan kegiatan penggunaan dana adalah untuk memperoleh penghasilan berupa pendapatan. Pendapatan bank mutlak harus ada untuk menjamin kontinuitas bank bersangkutan. Menurut Hasibuan (2009) pendapatan bank adalah: "Jika jumlah penghasilan yang diterima lebih besar daripada jumlah pengeluaran (biaya) yang dikeluarkan". Menurut Kasmir (2008) pendapatan dapat dibagi menjadi dua golongan, yaitu: "Pendapatan bunga (interest income) dan pendapatan non bunga (fee based income)."

Pendapatan bunga (interest income). Pendapatan yang diperoleh dalam bentuk bunga atas pemberian kredit sebagai penyalur dana kepada masyarakat baik perorangan atau badan usaha dan juga penempatan dana kepada bank lain. Sedangkan Pendapatan non bunga (fee based income). Pendapatan provisi, fee atau komisi yang diperoleh bank yang bukan merupakan pendapatan bunga. Pendapatan ini dapat juga diperoleh dari pemasaran produk maupun transaksi jasa perbankan.

\section{Fee Based Income}

Salah satu kegiatan perbankan selain menyalurkan dan menghimpun dana adalah memberikan jasa-jasa bank lainnya. Semakin lengkap jasa bank yang ditawarkan maka akan semakin baik, ini disebabkan jika nasabah akan melakukan transaksi perbankan dapat dilakukan di satu bank saja. Taswan (2006) menyatakan pengertian fee based income sebagai berikut: "Pengelolaan bank dalam melakukan kegiatannya juga selalu dituntut senantiasa menjaga keseimbangan pemeliharaan likuiditas dengan kebutuhan profitabilitas yang wajar serta modal yang cukup sesuai dengan penanamannya. Hal tersebut perlu dilakukan karena bank dalam usahanya selain menanamkan dana dalam aktiva produktif juga memberikan komitmen jasa-jasa lainnya yang menghasilkan fee based income (pendapatan non bunga)." 


\section{Buletin Ekonomi}

\section{Sumber-sumber Fee Based Income Inkaso}

Menurut Lukman Dendawijaya dalam bukunya yang berjudul Manajemen Perbankan (2001:29) "Inkaso adalah jasa yang diberikan bank atas permintaan nasabah untuk menagihkan pembayaran surat-surat atau dokumen berharga kepada pihak ketiga ditempat lain dimana bank yang bersangkutan mempunyai cabang atau pada bank lain". Inkaso merupakan kegiatan jasa Bank untuk melakukan amanat dari pihak ke tiga berupa penagihan sejumlah uang kepada seseorang atau badan tertentu di kota lain yang telah ditunjuk oleh si pemberi amanat. Sebagai imbalan jasa atas jasa tersebut biasanya bank menerapkan sejumlah tarif atau fee tertentu kapada nasabah atau calon nasabahnya. Tarif tersebut dalam dunia perbankan disebut dengan biaya inkaso. Sebagai imbalan bank meminta imbalan atau pembayarn atas penagihan tersebut disebut dengan biaya inkaso.

\section{Transfer}

Pengertian transfer menurut Lukman Dendawijaya dalam bukunya yang berjudul Manajemen Perbankan (2001:29) "Transfer adalah jasa yang diberikan bank dalam pengiriman uang antar bank atas permintaan pihak ketiga yang ditunjuk kepada penerima ditempat lain." Transfer adalah suatu kegiatan jasa bank untuk memindahkan sejumlah dana tertentu sesuai dengan perintah si pemberi amanat yang ditujukan untuk keuntungan seseorang yang ditunjuk sebagai penerima transfer. Baik transfer uang keluar atau masuk akan mengakibatkan adanya hubungan antar cabang yang bersifat timbal balik, artinya bila satu cabang mendebet cabang lain mengkredit.

\section{Safe Deposit Box}

Layanan Safe Deposit Box adalah jasa penyewaan kotak penyimpanan harta atau surat-surat berharga yang dirancang secara khusus dari bahan baja dan ditempatkan dalam ruang khasanah yang kokoh, tahan bongkar dan tahan api untuk memberikan rasa aman bagi penggunanya. Kondisi ketidakpastian selalu menambah rasa khawatir, terutama menyangkut keamanan barang-barang yang tidak ternilai harganya. Dalam menentukan pilihan untuk tempat penyimpanan yang tepat, tentunya harus memilih tempat yang terpercaya.

\section{Letter of Credit}

Letter of Credit atau dalam bahasa Indonesia disebut Surat Kredit Berdokumen merupakan salah satu jasa yang ditawarkan bank dalam rangka pembelian barang, berupa penangguhan pembayaran pembelian oleh pembeli sejak LC dibuka sampai dengan jangka waktu tertentu sesuai perjanjian. Berdasarkan pengertian tersebut, tipe perjanjian yang dapat difasilitasi LC terbatas hanya pada perjanjian jual - beli, sedangkan fasilitas yang diberikan adalah berupa penangguhan pembayaran.

\section{Travellers Cheque}

Travellers cheque yaitu cek wisata atau cek perjalanan yang digunakan untuk bepergian. Traveler's cek pertama kali diterbitkan pada tanggal 1 Januari 1772 oleh London Credit Exchange Company untuk digunakan dalam sembilan puluh kota-kota Eropa, dan pada tahun 1874 Thomas Cook telah mengeluarkan 'circular notes' (surat edaran) yang beroperasi pada caraTravellers chaque tersebut.

\section{Unsur-unsur Fee Based Income}

Menurut Dendawijaya (2009) pendapatan operasional bank terdiri atas: (1) Hasil bunga, (2) Provisi dan komisi, (3) Pendapatan valuta asing lainnya, dan (4) Pendapatan lainnya." Fee based income merupakan pendapatan operasional non bunga, maka dari itu unsur-unsur pendapatan operasional yang masuk ke dalamnya adalah: (1) Pendapatan atas 
komisi dan provisi, (2) Pendapatan dari hasil transaksi valuta asing atau devisa, (3) Pendapatan operasional lainnya.

\section{Pendapatan atas provisi dan komisi}

Yang termasuk disini adalah provisi dan komisi yang dipungut atau diterima oleh bank dari berbagai jasa keuangan yang dilakukan, seperti provisi kredit, provisi transfer, komisi pembelian/penjualan efek-efek, Letter of Credit, inkaso dan lain-lain. Sedangkan menurut N.Lapoliwa dan Daniel S. Kuswandi (2007:267) pengertian provisi dan komisi adalah: "Provisi kredit merupakan sumber pendapatan bank yang akan diterima dan diakui sebagai pendapatan pada saat kredit disetujui oleh bank. Biasanya provisi kredit langsung dibayarkan oleh nasabah yang bersangkutan. Komisi merupakan pendapatan bank yang sedang digiatkan akhir-akhir ini. Komisi merupakan beban yang diperhitungkan kepada para nasabah bank yang mempergunakan jasa bank. Komisi juga lainnya dibukukan langsung sebagai pendapatan pada saat bank menjual jasa kepada para nasabah."

\section{Pendapatan dari hasil transaksi valuta asing}

Yang termasuk disini adalah keuntungan yang diperoleh bank dari berbagai transaksi devisa, misalnya selisih kurs pembelian/penjualan valuta sing, selisih kurs karena konversi provisi, komisi, dan bunga yang diterima dari bank-bank di luar negeri. Sedangkan menurut N.Lapoliwa dan Daniel S. Kuswandi (2007:269) pengertian pendapatan transaksi valuta asing adalah: "Pendapatan yang timbul dari transaksi valas lazimnya berasal dari selisih kurs. Selisih kurs ini akan dimasukan kedalam pos pendapatan dalam laporan rugi laba. Laba atau rugi yang timbul dari transaksi valas harus diakui sebagai pendapatan atau beban dalam perhitungan laba rugi tahun berjalan”.

\section{Pendapatan operasional lainnya}

Yang termasuk disini adalah pendapatan lain yang merupakan hasil langsung dari kegiatan lainnya yang merupakan kegiatan operasional bank yang tidak termsuk ke dalam rekening pendapatan di atas, misalnya dividen yang diterima dari saham yang dimiliki.

Sedangkan menurut N.Lapoliwa dan Daniel S. Kuswandi (2007:270) pengertian pendapatan operasional adalah: "Pendapatan operasioanl lainnya adalah penerimaan deviden dari anak perusahaan atau penyertaan saham, laba rugi penjualan surat berharga pasar modal dan lainnya”.

\section{Laporan Keuangan}

Bagi pihak pemilik dan manajemen, tujuan utama dari analisis laporan keuangan adalah agar dapat mengetahui posisi keuangan perusahaan saat ini. Dengan mengetahui posisi keuangan, setelah dilakukan analisis laporan keuangan secara mendalam, akan terlihat apakah perusahaan dapat mencapai target yang telah direncanakan sebelumnya atau tidak. Pada akhirnya bagi pihak pemilik dan manajemen, dengan mengetahui posisi keuangan dapat merencanakan dan mengambil keputusan yang tepat tentang apa yang harus dilakukan kedepan. Perencanaan kedepan dengan cara menutupi kelemahan yang ada, mempertahankan posisi yang sudah sesuai dengan yang diinginkan, dan berupaya untuk meningkatkan lagi kekuatan yang sudah diperolehnya selama ini.

\section{Laba Bank}

Pada hakekatnya setiap perusahaan termasuk bank, memiliki tujuan yang sama yaitu memperoleh laba (profit oriental). Secara umum laba diperoleh dari seluruh penghasilan dikurangi dengan seluruh biaya. Besarnya laba yang didapat oleh perusahaan akan menjadi ukuran sukses atau tidaknya perusahaan tersebut. Menurut Drs. Lukman Dendawijaya dalam bukunya Management Perbankan, pengertian laba adalah "Laba adalah selisih antara pendapatan dengan biaya." (Dendawijaya, 2005;111). Sedangkan menurut Wild, 


\section{Buletin Ekonomi}

Subramanyam, dan Halsey (2005: 25) laba adalah: "Laba (earnings) atau laba bersih (net income) mengindikasikan profitabilitas perusahaan. Laba mencerminkan pengembalian kepada pemegang ekuitas untuk periode bersangkutan, sementara pos-pos dalam laporan merinci bagaimana laba didapat."

\section{Jenis-jenis Laba}

Laba kotor

Menurut Wild, Subramanyam, dan Halsey (2005: 120) laba kotor merupakan "pendapatan dikurangi harga pokok penjualan". Apabila hasil penjualan barang dan jasa tidak dapat menutupi beban yang langsung terkait dengan barang dan jasa tersebut atau harga pokok penjualan, maka akan sulit bagi perusahaan tersebut untuk bertahan.

\section{Laba operasi}

Menurut Stice, Stice, dan Skousen (2004: 243) “laba operasi mengukur kinerja operasi bisnis fundamental yang dilakukan oleh sebuah perusahaan dan didapat dari laba kotor dikurangi beban operasi". Laba operasi menunjukkan seberapa efisien dan efektif perusahaan melakukan aktivitas operasinya

\section{Laba sebelum pajak}

Laba sebelum pajak menurut Wild, Subramanyam, dan Halsey (2005: 25) merupakan "laba dari operasi berjalan sebelum cadangan untuk pajak penghasilan".

\section{Laba bersih}

Laba bersih menurut Wild, Subramanyam, dan Halsey (2005: 25) merupakan "laba dari bisnis perusahaan yang sedang berjalan setelah bunga dan pajak".

Berdasarkan uraian teori yang telah dibahas di atas, selanjutnya dapat disusun model teori sebagai berikut: 


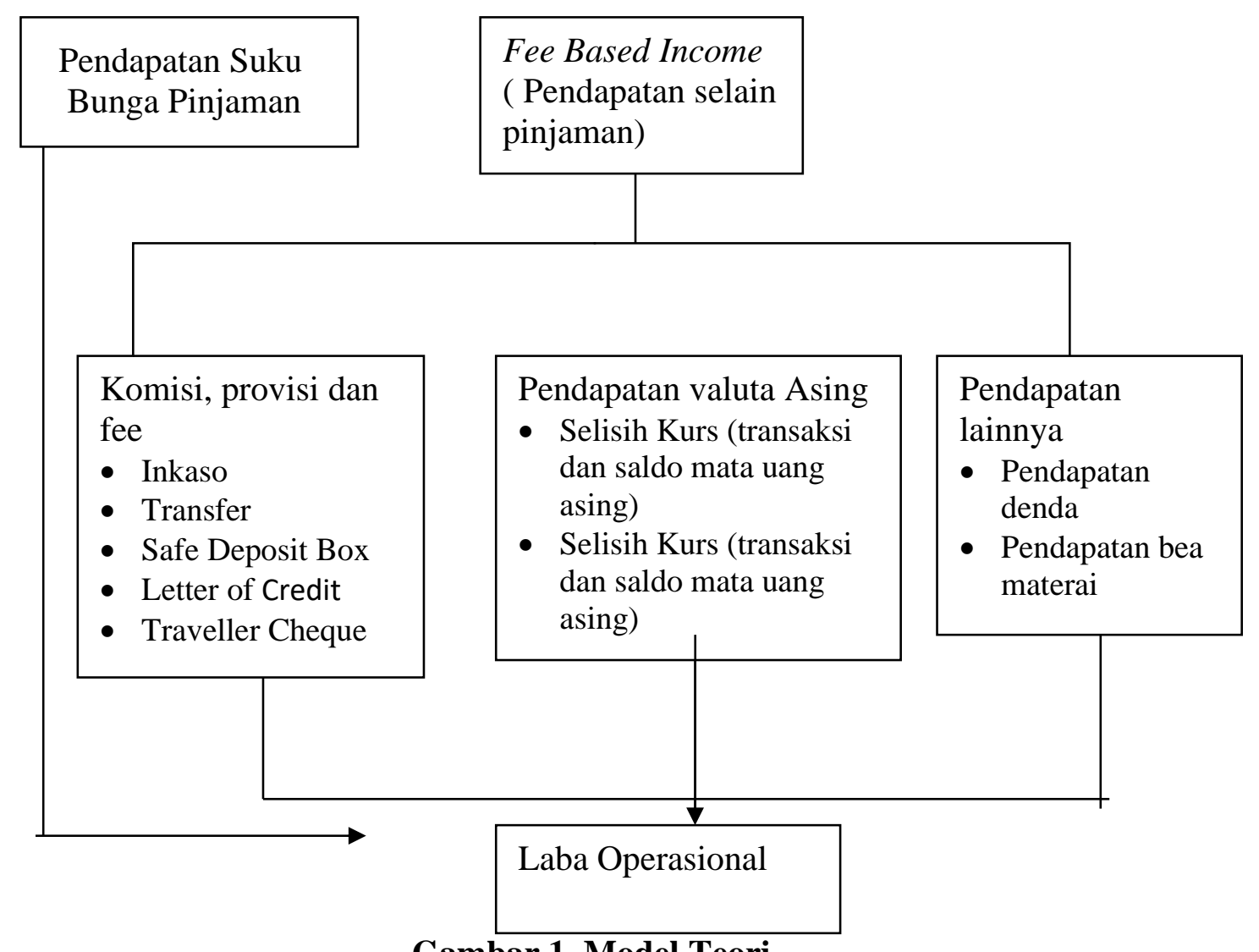

Gambar 1. Model Teori

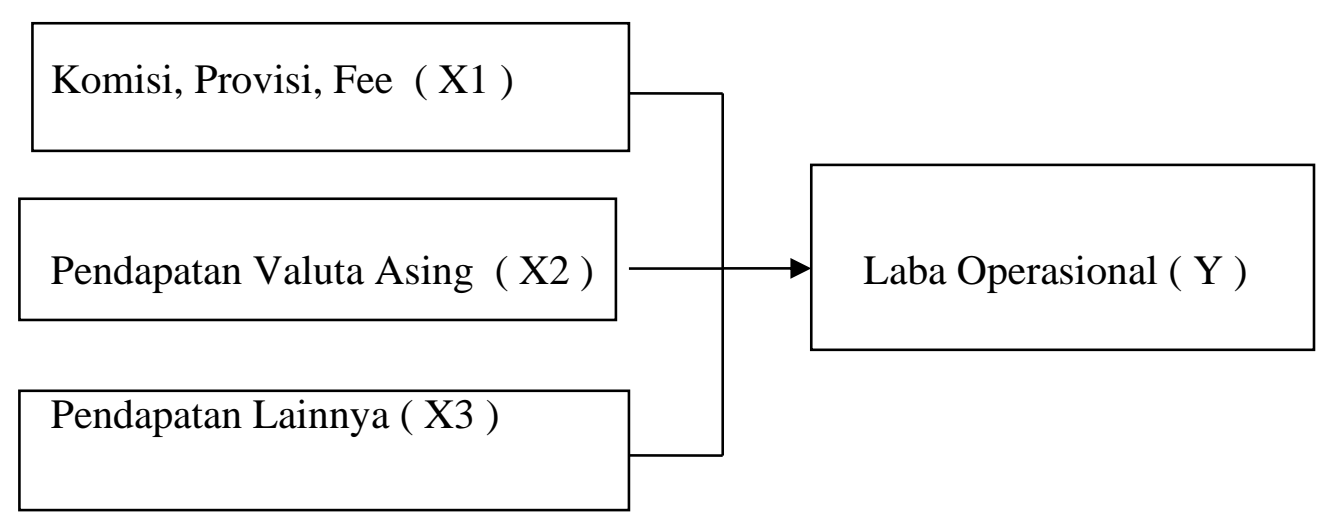

Gambar 2. Model Hipotesis

Hipotesis penelitian:

H1: Diduga komisi, provisi, fee, pendapatan valuta asing dan pendapatan lainnya berpengaruh secara parsial terhadap laba operasional

H2: Diduga komisi, provisi, fee, pendapatan valuta asing dan pendapatan lainnya berpengaruh secara simultan terhadap laba operasional 


\section{Buletin Ekonomi}

\section{METODE}

Metode yang digunakan dalam penelitian ini adalah metode deskriptif analisis dengan pendekatan kuantitatif. Data yang diperoleh selama penelitian kemudian diolah, dianalisis, dan diproses lebih lanjut dengan dasar teori dan penelitian terdahulu yang telah dipelajari untuk diambil kesimpulan. Menurut Sugiyono (2010:5), "Penelitian deskriptif adalah penelitian yang dilakukan untuk mengetahui nilai variabel, baik satu variabel atau lebih tanpa membuat hubungan antara variabel satu dengan variabel yang lain". Sedangkan pengertian kuantitatif menurut Sugiyono (2007:13), adalah: "Metode penelitian kuantitatif dapat diartikan sebagai metode penelitian yang berlandaskan pada filsafat positivisme, digunakan untuk meneliti pada populasi atau sampel tertentu, teknik pengambilan sampel pada umumnya dilakukan secara random, pengumpulan data menggunakan instrumen penelitian, analisis data bersifat kuantitatif atau statistik dengan tujuan untuk menguji hipotesis yang telah ditetapkan."

\section{Variabel Bebas atau Variabel Independen (Variabel X)}

Variabel independen yaitu variabel yang mempengaruhi variabel lain yang tidak bebas. Dalam penelitian ini yang menjadi variabel Bebas yaitu unsur-unsur di dalam fee based income, yaitu:

$\mathrm{X}_{1}=$ Komisi, provisi dan fee

$\mathrm{X}_{2}=$ Pendapatan valuta Asing atau devisa

$\mathrm{X}_{3}=$ Pendapatan Lainnya

\section{Variabel Terikat atau Variabel Dependen (Variabel Y)}

Variabel dependen yaitu variabel yang dipengaruhi oleh variabel bebas, maka yang menjadi variabel Y adalah "Laba Operasional". Yaitu selisih antara laba kotor dengan total beban operasi.

\section{Populasi dan Sampel Penelitian}

Populasi yang digunakan dalam penelitian ini adalah Bank Umum Milik Negara yang terdaftar di Bursa Efek Indonesia (BEI) dengan karekteristik tertentu. Terdapat empat Bank Umum Milik Negara yang terdaftar di BEI. Berikut ini merupakan daftar bank yang menjadi populasi penelitian :

Tabel 1.

Daftar Populasi Perbankan BUMN yang terdaftar di BEI

\begin{tabular}{clc}
\hline No. & \multicolumn{1}{c}{ Nama Bank } & Kode Bank \\
\hline 1 & PT Bank Rakyat Indonesia (Persero) Tbk & BBRI \\
2 & PT Bank Tabungan Negara (Persero) Tbk & BBTN \\
3 & PT Bank Negara Indonesia (Persero) Tbk & BBNI \\
4 & PT Bank Mandiri (Persero) Tbk & BMRI \\
\hline
\end{tabular}

Dalam penelitian ini, teknik yang digunakan untuk pengambilan sampel adalah nonprobability sampling dengan menggunakan metode purposive sampling yaitu teknik penentuan sampel dengan pertimbangan tertentu (Sugiyono, 2012). Sampel yang akan dipilih adalah laporan keuangan perusahaan perbankan BUMN yang terdaftar di BEI mulai dari tahun 2007-2014 (8 tahun).

Kriteria penetapan sampel adalah sebagai berikut: 


\section{Buletin Ekonomi}

Tabel 2.

Kriteria sampel

\begin{tabular}{clc}
\hline No. & \multicolumn{1}{c}{ Kriteria } & Jumlah \\
\hline 1 & Perbankan BUMN (Badan Umum Milik Negara) Persero. & 4 \\
2 & Laporan keuangan yang berakhir tanggal 31 Desember & 4 \\
3 & Menerbitkan laporan keuangan pada periode 2007-2014. & 4 \\
4 & Perbankan tidak mengalami kerugian selama periode tersebut. & 4 \\
5 & Perbankan telah terdaftar di BEI sebelum tanggal 31 Desember & 4 \\
& 2007 dan tidak delisting selama periode pengamatan 2007-2014. & \\
6 & Perbankan tidak mengalami transaksi akuisisi, merger dan & 4 \\
& konsolidasi pada periode 2007-2014. & \\
\hline
\end{tabular}

Tabel 3.

Daftar Sampel Perbankan BUMN

\begin{tabular}{clc}
\hline No. & \multicolumn{1}{c}{ Nama Bank } & Kode Bank \\
\hline 1 & PT Bank Rakyat Indonesia (Persero) Tbk & BBRI \\
2 & PT Bank Tabungan Negara (Persero) Tbk & BBTN \\
3 & PT Bank Negara Indonesia (Persero) Tbk & BBNI \\
4 & PT Bank Mandiri (Persero) Tbk & BMRI \\
\hline
\end{tabular}

\section{Analisis Deskriptif}

Analisis deskriptif merupakan penelitian yang dilakukan untuk mengetahui nilai variabel independen dan variabel dependen. Dalam analisis ini dilakukan pembahasan mengenai bagaimana variabel-variabel fee based income dan laba operasional pada perbankan BUMN yang terdaftar di BEI.

Uji statistik deskriptif merupakan pengujian statistik secara umum yang bertujuan untuk melihat distribusi data dari variabel yang digunakan sebagai sampel dalam penelitian ini. Data yang diperoleh dari hasil analisis deskriptif, menunjukkan nilai tertinggi (maximum), nilai terendah (minimum), rata-rata (mean) dan standar deviasi dari setiap variabel yang diteliti.

Berikut penjelasan yang termasuk dalam statistik deskriptif antara lain:

a. Rata-rata hitung (mean)

Mean merupakan teknik penjelasan kelompok yang didasarkan atas nilai rata-rata dari kelompok tersebut (Sugiyono, 2012:49).

Rata-rata hitung (mean) dapat dirumuskan sebagai berikut:

Keterangan:

$$
x=\frac{\sum \mathrm{X}_{\mathrm{i}}}{\mathrm{n}}
$$

$\mathrm{X}=$ Mean (rata-rata)

$\Sigma \mathrm{x}_{\mathrm{i}}=$ Jumlah nilai $\mathrm{X}$ ke i sampai ke $\mathrm{n}$

$\mathrm{n}=$ Jumlah sampel atau banyak data

b. Standar deviasi

Standar deviasi atau simpangan baku dari data yang telah disusun dalam tabel distribusi frekuensi atau data bergolong, dapat dihitung dengan rumus sebagai berikut:

$$
S=\sqrt{\frac{\sum \mathrm{X}^{2}-\frac{\left(\sum \mathrm{x}\right)^{2}}{\mathrm{n}}}{\mathrm{n}-1}}
$$




\title{
Buletin Ekonomi
}

\author{
Keterangan: \\ S : Simpangan Baku \\ Me : Rata-rata nilai \\ $\Sigma x$ : Nilai $X$ ke i sampai ke $n$ \\ $\mathrm{n}$ : Jumlah sampel atau banyak data
}

\section{Uji Asumsi Klasik}

Uji Normalitas. Uji normalitas bertujuan menguji apakah dalam model penelitian variabel terdistribusi secara normal. Uji normalitas data dalam penelitian ini menggunakan pengujian grafik normal PP Plot dan One-Sample Kolmogorov Smirnov test yang terdapat dalam program SPSS 17.0 for Windows. Data dikatakan terdistribusi dengan normal apabila residual terdistribusi dengan normal yaitu memiliki tingkat signifikansi diatas 5\% (Ghozali, 2005). Pengujian Normalitas dilakukan untuk melihat apakah nilai residual yang diperoleh dari model mengikuti distribusi normal atau tidak. Hasil pengujian menunjukkan residual berdistribusi normal.

Uji Multikolinieritas. Uji Multikolinieritas dilakukan untuk menguji apakah model regresi ditemukan adanya korelasi antar variabel bebas (independent). Model regresi yang baik adalah yang tidak terjadi korelasi diantara variabel bebas (tidak terjadi multikolinieritas). Untuk menguji multikolinieritas dilakukan dengan 2 cara, yaitu:

a) Melihat nilai Tolerance.

1. Tidak terjadi Multikoliniaritas, jika nilai Tolerence $>0,10$.

2. Terjadi Multikoliniaritas, jika nilai Tolerence $<=0,10$.

b) Melihat nilai VIF (Variance Inflation Factor).

1. Tidak terjadi Multikoliniaritas, jika nilai VIF $<10,00$.

2. Terjadi Multikoliniaritas, jika nilai VIF $>=10,00$.

Uji Heteroskedastisitas. Uji heteroskedastisitas dilakukan untuk menguji apakah dalam model regresi terjadi ketidaksamaan variance dari residual suatu pengamatan ke pengamatan yang lain. Model regresi yang baik adalah yang homokedastisitas atau tidak heteroskedastisitas. Uji heterokesdaksitas dalam penelitian ini diuji dengan scaterplots.

Uji Autokorelasi. Autokolerasi dimaksudkan untuk menguji suatu keadaan di mana pada model regresi terdapat hubungan antara variabel atau dengan kata lain terdapat korelasi antara residual pada periode $t$ dengan residual pada periode sebelumnya ( $t-1)$. Model regresi yang baik adalah yang tidak terdapat masalah autokorelasi. Apabila hasil uji Durbin-Watson tidak dapat disimpulkan apakah terdapat autokorelasi atau tidak maka dilanjutkan dengan run test. Apabila nilai uji Durbin-Watson mendekati nilai 2, maka dapat dikatakan bahwa tidak terjadi autokorelasi pada variabel bebas. Apabila terdapat autokorelasi cara menanggulangi masalahnya yaitu dengan cara mentransformasikan data atau bisa juga dengan mengubah model regresi ke dalam bentuk persamaan beda umum (generalized difference equation). Selain itu juga dapat dilakukan dengan memasukkan variabel lag dari variabel terikat menjadi salah satu variabel bebas.

\section{Uji Regresi Berganda}

Analisis regresi berganda ditujukan untuk mengetahui pengaruh lebih dari satu variable bebas yakni Pendapatan Komisi, provisi dan fee $\left(\mathrm{X}_{1}\right)$, Pendapatan valuta Asing atau devisa $\left(\mathrm{X}_{2}\right)$, Pendapatan Lainnya $\left(\mathrm{X}_{3}\right)$ terhadap variabel terikat $(\mathrm{Y})$ berupa Laba Operasional,

\section{Pengujian Hipotesis}

Pengujian hipotesis dalam penelitian ini, penulis menetapkan dengan menggunakan uji signifikan, dengan penetapan hipotesis nol (H0) dan hipotesis alternatif (Ha).Hipotesis nol 


\section{Buletin Ekonomi}

$\left(\mathrm{H}_{0}\right)$ adalah suatu hipotesis yang menyatakan bahwa tidak ada pengaruh signifikan antara riabel independen dan variabel dependen. Hipotesis alternatif (Ha) adalah suatu hipotesis yang menyatakan bahwa ada pengaruh signifikan antara variabel independen dengan variabel dependen.

Uji t. Kriteria pengujian apakah hipotesis itu ditolak atau tidak ditolak sebagai berikut:

a) Jika nilai $t$ hitung $<$ nilai $t$ tabel, maka $\mathrm{H}_{0}$ diterima dan Ha ditolak.

b) Jika nilai $t_{\text {hitung }}>$ nilai $t_{\text {tabel, }}$, maka $\mathrm{H}_{0}$ ditolak dan Ha diterima.

Kriteria pengujian ditetapkan dengan membandingkan nilai $t$ hitung dari perhitungan kemudian dibandingkan dengan $t$ tabel dengan menggunakan tabel nilai-nilai dalam distribusi $t$ dengan tingkat signifikan 0,05 .

Uji F. Kriteria pengujian apakah hipotesis itu ditolak atau tidak ditolak sebagai berikut:

a) Jika nilai probabilitas $<0,05$ maka $\mathrm{H}_{0}$ ditolak dan Ha diterima.

b) Jika nilai probabilitas $>0,05$ maka $\mathrm{H}_{0}$ diterima dan Ha ditolak.

\section{Koefisien Determinasi $\left(\boldsymbol{R}^{2}\right)$}

Koefisien determinasi pada regresi berganda sering diartikan sebagai seberapa besar kemampuan semua variabel bebas dalam menjelasakan varians dan variabel terikatnya. Secara sederhana koefisien determinasi dihitung dengan menguadratkan koefisien korelasi (R) ini mencerminkan seberapa besar variasi dari variabel terikat $\mathrm{Y}$ dapat diterangkan oleh variabel bebas X. Bila nilai koefisien determinasi sama dengan $0(\mathrm{R} 2=0)$, artinya variasi dari Y tidak dapat diterangkan oleh X sama sekali. Sementara bila R2 $=1$, artinya variasi dari Y secara keseluruhan dapat diterangankan atau dipengaruhi oleh variabel X.

\section{ANALISIS DAN PEMBAHASAN}

Tabel 4.

Analisis Deskriptif Variabel Pendapatan Komisi, Provisi dan Fee $\left(\mathbf{X}_{1}\right)$

Statistics

\begin{tabular}{|c|c|c|c|c|c|}
\hline \multirow{3}{*}{$\mathrm{N}$} & \multirow{3}{*}{$\begin{array}{l}\text { Valid } \\
\text { Missing }\end{array}$} & \multicolumn{2}{|r|}{ BBTN } & BBNI & \multirow[t]{3}{*}{ BMRI } \\
\hline & & 8 & 8 & 8 & \\
\hline & & 0 & 0 & 0 & \\
\hline \multicolumn{2}{|c|}{ Mean } & 3577383.37 & 3609466.50 & 2845333.25 & 5939520.37 \\
\hline \multicolumn{2}{|c|}{ Median } & 3280240.50 & 3609466.50 & 2521579.00 & 5822537.00 \\
\hline \multicolumn{2}{|c|}{ Mode } & $1865164.00^{\mathrm{a}}$ & $2484115.00^{\mathrm{a}}$ & $1575263.00^{\mathrm{a}}$ & $2900182.00^{\mathrm{a}}$ \\
\hline \multicolumn{2}{|c|}{ Std. Deviation } & 1363374.57 & 787581.98 & 1169870.57 & 2368103.04 \\
\hline \multicolumn{2}{|c|}{ Minimum } & 1865164.00 & 2484115.00 & 1575263.00 & 2900182.00 \\
\hline \multicolumn{2}{|c|}{ Maximum } & 6072460.00 & 4734818.00 & 5027135.00 & 9131975.00 \\
\hline \multicolumn{2}{|c|}{ Sum } & 28619067.00 & 28875732.00 & 22762666.00 & 47516163.00 \\
\hline
\end{tabular}

Berdasarkan tabel di atas diketahui bahwa rata-rata pendapatan komisi, provisi dan fee untuk Bank Rakyat Indonesia (BRI) adalah sebesar 3.577.383,37 juta rupiah, nilai minimumnya sebesar 1.865.164,00 juta rupiah dan nilai maksimum sebesar 6.072.460,00 juta rupiah. Kemudian rata-rata pendapatan komisi, provisi dan fee untuk Bank Tabungan Negara (BTN) adalah sebesar 3.609.466,50 juta rupiah, nilai minimumnya sebesar 2484115.00 juta rupiah dan nilai maksimum sebesar 4.734.818,00 juta rupiah. Selanjutnya rata-rata pendapatan komisi, provisi dan fee untuk Bank Negara Indonesia (BNI) adalah sebesar 2845333.25 juta rupiah, nilai minimumnya sebesar 1.575.263,00 juta rupiah dan nilai 


\section{Buletin Ekonomi}

maksimum sebesar 5.027.135,00 juta rupiah. Dan yang terakhir rata-rata pendapatan komisi, provisi dan fee untuk Bank Mandiri adalah sebesar 5.939.520,37 juta rupiah, nilai minimumnya sebesar 2.900.182,00 juta rupiah dan nilai maksimum sebesar 9.131.975,00 juta rupiah. Dari keempat bank tersebut diketahui bahwa rata-rata pendapatan komisi, provisi dan fee tertinggi adalah Bank Mandiri.

Tabel 5.

Analisis Deskriptif Variabel Pendapatan Transaksi Valas atau Devisa $\left(\mathbf{X}_{2}\right)$ Statistics

\begin{tabular}{lrrrrr}
\hline & \multicolumn{1}{c}{ BBRI } & \multicolumn{1}{c}{ BBTN } & BBNI & \multicolumn{1}{c}{ BMRI } \\
N $\quad$ Valid & 8 & 8 & 8 & 8 \\
\multicolumn{1}{c}{ Missing } & 0 & 0 & 0 & 0 \\
\hline Mean & 39911057.75 & 4248218.50 & 286981.37 & 984485.75 \\
Median & 35455421.00 & 4019609.00 & 179183.50 & 801032.50 \\
Mode & $29811657.00^{\mathrm{a}}$ & $2383457.00^{\mathrm{a}}$ & $166055.00^{\mathrm{a}}$ & $506093.00^{\mathrm{a}}$ \\
Std. Deviation & 10508341.99 & 1417906.14 & 205362.00 & 492642.17 \\
Minimum & 29811657.00 & 2383457.00 & 166055.00 & 506093.00 \\
Maximum & 58778549.00 & 6275839.00 & 692645.00 & 1853099.00 \\
Sum & 319288462.00 & 33985748.00 & 2295851.00 & 7875886.00 \\
\hline
\end{tabular}

Berdasarkan tabel di atas diketahui bahwa rata-rata pendapatan transaksi valuta asing atau devisa untuk Bank Rakyat Indonesia (BRI) adalah sebesar 39.911.057,75 juta rupiah, nilai minimumnya sebesar 29.811.657,00 juta rupiah dan nilai maksimum sebesar 58.778.549,00 juta rupiah. Kemudian rata-rata pendapatan transaksi valuta asing atau devisa untuk Bank Tabungan Negara (BTN) adalah sebesar 4.248.218,50 juta rupiah, nilai minimumnya sebesar 2.383.457,00 juta rupiah dan nilai maksimum sebesar 6.275.839,00 juta rupiah. Selanjutnya rata-rata pendapatan transaksi valuta asing atau devisa untuk Bank Negara Indonesia (BNI) adalah sebesar 286.981,37 juta rupiah, nilai minimumnya sebesar 166.055,00 juta rupiah dan nilai maksimum sebesar 692.645,00 juta rupiah. Dan yang terakhir rata-rata pendapatan transaksi valuta asing atau devisa untuk Bank Mandiri adalah sebesar 984.485,75 juta rupiah, nilai minimumnya sebesar 506.093,00 juta rupiah dan nilai maksimum sebesar 1.853.099,00 juta rupiah. Dari keempat bank tersebut diketahui bahwa rata-rata pendapatan transaksi valuta asing atau devisa tertinggi adalah Bank Rakyat Indonesia.

Tabel 6.

Analisis Deskriptif Variabel Pendapatan Lainnya $\left(\mathbf{X}_{3}\right)$

\begin{tabular}{lrrrrr}
\hline \multicolumn{6}{c}{ Statistics } \\
\hline N $\quad$ Valid & \multicolumn{1}{c}{ BBRI } & BBTN & BBNI & \multicolumn{1}{c}{ BMRI } \\
\multicolumn{1}{c}{ Missing } & 8 & 8 & 8 & 8 \\
\hline Mean & 0 & 0 & 0 & 0 \\
Median & 468688.25 & 491033.87 & 477254.75 & 2496224.37 \\
Mode & 353171.00 & 499953.50 & 482493.50 & 3069260.50 \\
Std. Deviation & $141008.00^{\mathrm{a}}$ & $179329.00^{\mathrm{a}}$ & $183393.00^{\mathrm{a}}$ & $344757.00^{\mathrm{a}}$ \\
Minimum & 331213.17 & 266133.89 & 220756.52 & 1776141.78 \\
Maximum & 141008.00 & 179329.00 & 183393.00 & 344757.00 \\
& 982087.00 & 894820.00 & 765099.00 & 4412400.00
\end{tabular}




\section{Buletin Ekonomi}

\begin{tabular}{lllll} 
Sum & 3749506.00 & 3928271.00 & 3818038.00 & 19969795.00 \\
\hline
\end{tabular}

Berdasarkan tabel di atas diketahui bahwa rata-rata pendapatan lainnya untuk Bank Rakyat Inonesia (BRI) adalah sebesar 468.688.25 juta rupiah, nilai minimumnya sebesar 141.008.00 juta rupiah dan nilai maksimum sebesar 982.087 .00 juta rupiah. Kemudian ratarata pendapatan lainnya untuk Bank Tabungan Negara (BTN) adalah sebesar 491.033.87 juta rupiah, nilai minimumnya sebesar 179.329 .00 juta rupiah dan nilai maksimum sebesar 894.820.00 juta rupiah. Selanjutnya rata-rata pendapatan lainnya untuk Bank Negara Indonesia (BNI) adalah sebesar 477.254.75 juta rupiah, nilai minimumnya sebesar 183393.00 juta rupiah dan nilai maksimum sebesar 765.099.00 juta rupiah. Dan yang terakhir rata-rata pendapatan lainnya untuk Bank Mandiri adalah sebesar 2.496.224.37 juta rupiah, nilai minimumnya sebesar 344.757.00 juta rupiah dan nilai maksimum sebesar 4.412.400.00 juta rupiah. Dari keempat bank tersebut diketahui bahwa rata-rata pendapatan lainnya tertinggi adalah Bank Mandiri.

Tabel 7.

Analisis Deskriptif Variabel Laba Operasional (Y)

\begin{tabular}{lrrrrr}
\multicolumn{7}{c}{ Statistics } \\
\hline N & \multicolumn{1}{c}{ BBRI } & \multicolumn{1}{c}{ BBTN } & BBNI & \multicolumn{1}{c}{ BMRI } \\
& Valid & 8 & 8 & 8 & 8 \\
\multicolumn{1}{c}{ Missing } & 0 & 0 & 0 & 0 \\
\hline Mean & 17320571.87 & 1357689.37 & 6907039.75 & 15406900.62 \\
Median & 15993115.50 & 1394733.00 & 6375800.50 & 15045476.50 \\
Mode & $7661849.00^{\mathrm{a}}$ & $677621.00^{\mathrm{a}}$ & $1866864.00^{\mathrm{a}}$ & $5664068.00^{\mathrm{a}}$ \\
Std. Deviation & 7704868.45 & 506992.69 & 3983173.82 & 7323039.68 \\
Minimum & 7661849.00 & 677621.00 & 1866864.00 & 5664068.00 \\
Maximum & 28361877.00 & 2135909.00 & 13346291.00 & 25978106.00 \\
Sum & 138564575.00 & 10861515.00 & 55256318.00 & 123255205.00 \\
\hline
\end{tabular}

Berdasarkan tabel di atas diketahui bahwa rata-rata laba operasional untuk Bank Rakyat Indonesia (BRI) adalah sebesar 17.320.571.87 juta rupiah, nilai minimumnya sebesar 7.661.849.00 juta rupiah dan nilai maksimum sebesar 28.361.877.00 juta rupiah. Kemudian rata-rata laba operasional untuk Bank Tabungan Negara (BTN) adalah sebesar 1.357.689.37 juta rupiah, nilai minimumnya sebesar 677.621 .00 juta rupiah dan nilai maksimum sebesar 2.135.909.00 juta rupiah. Selanjutnya rata-rata laba operasional untuk Bank Negara Indonesia (BNI) adalah sebesar 6.907.039.75 juta rupiah, nilai minimumnya sebesar 1.866.864.00 juta rupiah dan nilai maksimum sebesar 1.334.6291.00 juta rupiah. Dan yang terakhir rata-rata laba operasional untuk Bank Mandiri adalah sebesar 15.406.900.62 juta rupiah, nilai minimumnya sebesar 5664068.00 juta rupiah dan nilai maksimum sebesar 25.978.106.00 juta rupiah. Dari keempat bank tersebut diketahui bahwa rata-rata laba operasional tertinggi adalah Bank Rakyat Indonesia (BRI).

\section{Hasil Pengujian Normalitas}


Normal P-P Plot of Regression Standardized Residual

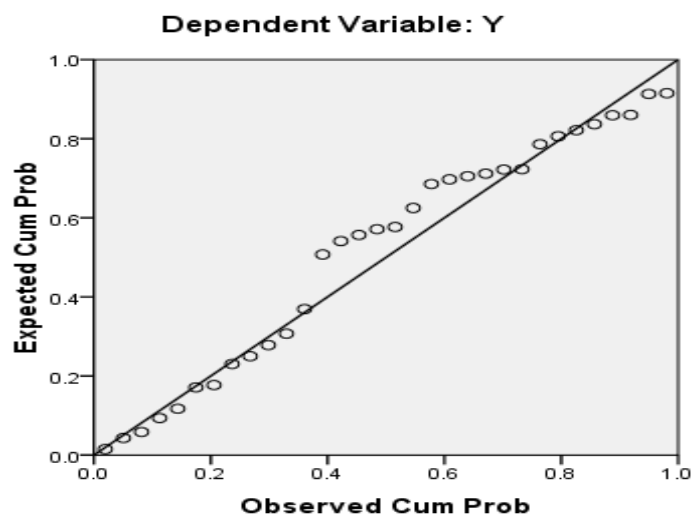

Gambar 3. Grafik Normalitas

Dari gambar di atas dapat dilihat titik-titik berada di sekitar garis diagonal. Titik- titik yang menyebar disekitar garis diagonal menunjukkan residual berdistribusi normal.

\section{Hasil Pengujian Multikolinieritas}

Hasil pengujian asumsi Multikolinieritas menunjukkan di dalam model tidak terjadi Multikolinieritas. Hal ini dapat dilihat dari matriks korelasi antara variabel bebas pada tabel di bawah ini.

Tabel 8.

Hasil Pengujian Multikolinieritas

Coefficients $^{\text {a }}$

\begin{tabular}{|c|c|c|c|c|c|c|c|c|}
\hline \multirow[b]{2}{*}{ Model } & & \multicolumn{2}{|c|}{$\begin{array}{l}\text { Unstandardized } \\
\text { Coefficients }\end{array}$} & \multicolumn{2}{|l|}{$\begin{array}{c}\text { Standardize } \\
\text { d } \\
\text { Coefficients }\end{array}$} & \multicolumn{3}{|c|}{$\begin{array}{l}\text { Collinearity } \\
\text { Statistics }\end{array}$} \\
\hline & & B & Std. Error & Beta & $\mathbf{t}$ & Sig. & $\begin{array}{c}\text { Toleranc } \\
\text { e }\end{array}$ & VIF \\
\hline 1 & $\begin{array}{l}\text { (Constan } \\
\text { t) }\end{array}$ & $-2.529 \mathrm{E} 6$ & $2.220 \mathrm{E} 6$ & & -1.139 & .264 & & \\
\hline & $\mathrm{X} 1$ & 1.706 & .813 & .377 & 2.098 & .045 & .196 & 5.107 \\
\hline & $\mathrm{X} 2$ & .309 & .042 & .638 & 7.329 & .000 & .837 & 1.194 \\
\hline & X3 & 2.503 & 1.254 & .367 & 1.996 & .056 & .188 & 5.332 \\
\hline
\end{tabular}

a. Dependent Variable: Y

Pengujian multikolinieritas dapat diketahui dengan melihat VIF dan nilai tolerance yang diperoleh. Jika nilai nilai toleransi $>0,10$ dan nilai VIF $<$ dari 10 maka dapat disimpulkan tidak terjadi multikolinieritas. Dari hasil pengujian diketahui bahwa seluruh nilai VIF $<10$ dan nilai tolerance $>0,10$ sehingga disimpulkan bahwa tidak terjadi multikolinieritas. Nilai tolerance dan VIF untuk masing-masing variabel antara lain Pendapatan Komisi, provisi dan fee sebesar 0,196 dan 5,107; Variabel Pendapatan valuta Asing atau devisa sebesar 0,837, dan 1,194 serta variabel pendapatan lainnya sebesar 0,188 dan 5,332 .

Hasil Pengujian Heteroskedastisitas 
Scatterplot

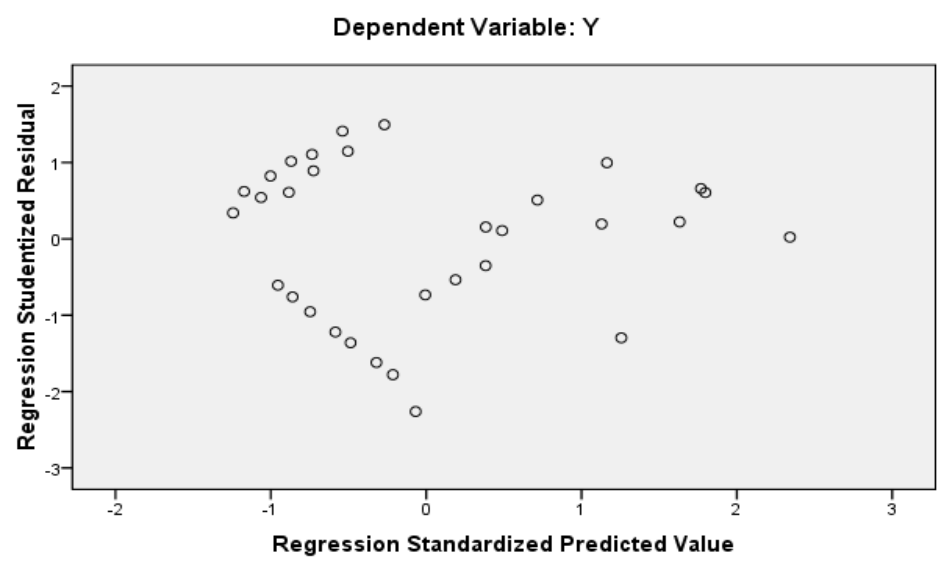

Gambar 4. Uji Heteroskedastisitas dengan Scatterplot

Hasil uji heteroskedastisitas pada gambar diatas menunjukan bahwa titik-titik tersebar di atas dan di bawah angka nol. Titik-titik menyebar dan tidak membentuk pola tertentu yang teratur sehingga dapat disimpulkan bahwa dalam model regresi tidak terjadi heteroskedastisitas.

\section{Hasil Pengujian Autokolerasi}

Tabel 9.

Hasil Pengujian Autokolerasi Model Summary

\begin{tabular}{llrrrrr}
\hline $\begin{array}{l}\text { Mode } \\
\mathbf{l}\end{array}$ & \multicolumn{2}{c}{ R } & R Square & $\begin{array}{l}\text { Adjusted R } \\
\text { Square }\end{array}$ & $\begin{array}{c}\text { Std. Error of the } \\
\text { Estimate }\end{array}$ & $\begin{array}{l}\text { Durbin- } \\
\text { Watson }\end{array}$ \\
\hline 1 & $.907^{\text {a }}$ & .823 & .804 & 3766325.55184 & 2.827 \\
\hline
\end{tabular}

Hasil uji autokorelasi dengan menggunakan uji Durbin Watson menunjukan nilai DW hitung sebesar 2,827. Hasil DW hitung lebih dari \pm 2 . Sehingga dapat disimpulkan bahwa dalam model regresi tidak terjadi autokorelasi.

Tabel 10.

Analisis Regresi Linier Berganda

Coefficients $^{\mathbf{a}}$

\begin{tabular}{|c|c|c|c|c|c|c|}
\hline \multirow[b]{2}{*}{ Model } & & \multicolumn{2}{|c|}{$\begin{array}{l}\text { Unstandardized } \\
\text { Coefficients }\end{array}$} & \multirow{2}{*}{$\begin{array}{c}\text { Standardized } \\
\text { Coefficients } \\
\text { Beta } \\
\end{array}$} & \multirow[b]{2}{*}{$\mathbf{t}$} & \multirow[b]{2}{*}{ Sig. } \\
\hline & & B & Std. Error & & & \\
\hline 1 & $\begin{array}{l}\text { (Constant } \\
\text { ) }\end{array}$ & -2.5296 & $2.220 \mathrm{E} 6$ & & -1.139 & .264 \\
\hline & $\mathrm{X} 1$ & 1.706 & .813 & .377 & 2.098 & .045 \\
\hline & $\mathrm{X} 2$ & .309 & .042 & .638 & 7.329 & .000 \\
\hline & $\mathrm{X} 3$ & 2.503 & 1.254 & .367 & 1.996 & .056 \\
\hline
\end{tabular}




\section{Coefficients $^{\text {a }}$}

\begin{tabular}{|c|c|c|c|c|c|c|c|}
\hline \multirow{2}{*}{\multicolumn{2}{|c|}{ Model }} & \multicolumn{2}{|c|}{$\begin{array}{l}\text { Unstandardized } \\
\text { Coefficients }\end{array}$} & \multirow{2}{*}{\multicolumn{2}{|c|}{$\begin{array}{c}\text { Standardized } \\
\text { Coefficients } \\
\text { Beta } \\
\end{array}$}} & \multirow[b]{2}{*}{$\mathbf{t}$} & \multirow[b]{2}{*}{ Sig. } \\
\hline & & B & Std. Error & & & & \\
\hline 1 & (Constant & -2.5296 & $2.220 \mathrm{E} 6$ & & & -1.139 & .264 \\
\hline & $\mathrm{X} 1$ & 1.706 & .813 & & .377 & 2.098 & .045 \\
\hline & $\mathrm{X} 2$ & .309 & .042 & & .638 & 7.329 & .000 \\
\hline & X3 & 2.503 & 1.254 & & .367 & 1.996 & .056 \\
\hline
\end{tabular}

a. Dependent Variable: $\mathrm{Y}$

Persamaan regresi linier sebagai berikut:

$$
Y=-2,529+1,706 \times 1+0,309 \times 2+2,503 \times 3+2,220
$$

Tabel 11.

Uji t

Coefficients $^{\text {a }}$

\begin{tabular}{llrrrrr}
\hline & \multicolumn{2}{c}{$\begin{array}{c}\text { Unstandardized } \\
\text { Coefficients }\end{array}$} & \multicolumn{2}{c}{$\begin{array}{c}\text { Standardized } \\
\text { Coefficients }\end{array}$} & \\
Model & & B & Std. Error & Beta & \multicolumn{1}{c}{ t } & \multicolumn{1}{c}{ Sig. } \\
\hline 1 & (Constant) & $-2.529 \mathrm{E} 6$ & $2.220 \mathrm{E} 6$ & & -1.139 & .264 \\
& X1 & 1.706 & .813 & .377 & 2.098 & .045 \\
& X2 & .309 & .042 & .638 & 7.329 & .000 \\
& X3 & 2.503 & 1.254 & .367 & 1.996 & .056 \\
\hline
\end{tabular}

a. Dependent Variable: Y

Dari tabel di atas dapat dilihat bahwa variable pendapatan komisi, provisi dan fee $\left(\mathrm{X}_{1}\right)$ memiliki nilai t hitung sebesar 2,098 dimana hasil yang didapatkan lebih besar dari t tabel untuk sampel sebanyak 32 adalah (2.042) dengan nilai probabilitas $0,045<0,05$ maka dapat disimpulkan bahwa terdapat berpengaruh yang nyata (signifikan) pendapatan komisi, provisi dan fee terhadap laba operasional dengan taraf kebenaran 95\%. Untuk daerah penolakan dapat digambarkan sebagai berikut:

Selanjutnya variabel pendapatan valuta asing atau devisa $\left(\mathrm{X}_{2}\right)$ memiliki nilai statistik $\mathrm{t}$ hitung sebesar 7,329 dimana hasil yang didapatkan lebih besar dari t tabel untuk sampel sebanyak 32 adalah (2.042) dengan nilai probabilitas $0,000<0,05$, maka dapat disimpulkan bahwa terdapat berpengaruh yang signifikan atau nyata pendapatan valuta asing atau devisa terhadap laba operasional dengan taraf kebenaran $95 \%$.

Selanjutnya variabel pendapatan lainnya $\left(\mathrm{X}_{3}\right)$ memiliki nilai t hitung sebesar 1,996 dimana hasil yang didapatkan lebih kecil dari t tabel $(1,693)$ dengan nilai probabilitas $0,056>$ 0,05 maka dapat disimpulkan bahwa terdapat berpengaruh positif yang tidak signifikan pendapatan lainnya terhadap laba operasional dengan taraf kebenaran $95 \%$.

\section{Uji F}

\section{Tabel 12.}

Uji F

ANOVA ${ }^{b}$

\begin{tabular}{lllllll}
\hline Model & Sum of Squares & Df & Mean Square & F & Sig. \\
\hline
\end{tabular}


$1 \quad$ Regression 1841297842450007. 800

Residual $\quad 397185828548485.9$ 40

Total 2238483670998493 800
$3 \begin{array}{rr}613765947483335.9 & \\ 00 & 43.268\end{array}$

$.000^{\mathrm{a}}$

\section{$28{ }^{14185208162445.92}$}

31

a. Predictors: (Constant), $\mathrm{X}_{3}, \mathrm{X}_{2}, \mathrm{X}_{1}$

b. Dependent Variable: Y

Berdasarkan tabel di atas maka didapatkan hasil dari uji statistik $\mathrm{f}$ didapatkan nilai statistikf hitung 43,268 dimana hasil ini lebih besar dari $\mathrm{F}$ tabel pada $\mathrm{n}$ sebesar 32 didapatkan $(1,84)$ sehingga Ho ditolak yang mana dapat disimpulkan bahwa pendapatan komisi, provisi dan fee; pendapatan valuta asing atau devisa; dan pendapatan lainnya secara simultan atau bersama-sama berpengaruh signifikan terhadap laba operasional.

\section{Uji Koefisien Determinasi $\mathbf{R}^{2}$}

Tabel 13.

Koefisien Determinasi $\mathbf{R}^{2}$

Model Summary ${ }^{b}$

\begin{tabular}{lrrrrr}
\hline Model & R & R Square & $\begin{array}{c}\text { Adjusted R } \\
\text { Square }\end{array}$ & $\begin{array}{c}\text { Std. Error of the } \\
\text { Estimate }\end{array}$ & $\begin{array}{l}\text { Durbin- } \\
\text { Watson }\end{array}$ \\
\hline 1 & $.907^{\mathrm{a}}$ & .823 & .804 & 3766325.55184 & 2.827 \\
\hline
\end{tabular}

a. Predictors: (Constant), X3, X2, X1

b. Dependent Variable: Y

Nilai R Square sebesar 0,832 menunjukkan bahwa variabel laba operasional (Y) dipengaruhi atau dapat dijelaskan oleh pendapatan komisi, provisi dan fee; pendapatan valuta asing atau devisa; dan pendapatan lainnya $\left(\mathrm{X}_{1,2,3}\right)$ mempengaruhi laba operasional sebesar $83,2 \%$, dan sisanya $16,8 \%$ dipengaruhi oleh faktor lain yang tidak dihitung dalam penelitian ini. Standart error of estimate artinya mengukur variasi dari nilai yang diprediksi. Nilai standart error off estimate 3766325 semakin kecil standart error of estimate berarti model semakin baik.

Pada hakekatnya setiap perusahaan termasuk bank, memiliki tujuan yang sama yaitu memperoleh laba (profit oriented). Secara umum laba operasi diperoleh dari seluruh penghasilan dikurangi dengan seluruh biaya. Besarnya laba operasi yang didapat oleh perusahaan akan menjadi ukuran sukses atau tidaknya perusahaan tersebut dalam menjalankan operasinya. Pendapatan provisi, fee atau komisi yang diperoleh bank yang bukan merupakan pendapatan bunga. Pendapatan ini dapat juga diperoleh dari pemasaran produk maupun transaksi jasa perbankan.

Hasil penelitian menunjukkan bahwa koefisien ( b1) pendapatan komisi, provisi dan fee $=1,706$. Dari angka tersebut dapat diketahui bahwa terdapat pengaruh positif pendapatan komisi, provisi dan fee $\left(\mathrm{X}_{1}\right)$ terhadap laba operasional $(\mathrm{Y})$ yang berarti dengan adanya kenaikan pendapatan komisi, provisi dan fee akan diikuti oleh peningkatan laba operasional. Kemudian nilai $\mathrm{t}$ hitung sebesar 2,098 dimana hasil yang didapatkan lebih besar dari t tabel untuk sampel sebanyak 32 adalah (2.042) dengan nilai probabilitas $0,045<0,05$ maka dapat disimpulkan bahwa terdapat berpengaruh yang nyata (signifikan) pendapatan komisi, provisi 


\section{Buletin Ekonomi}

dan fee terhadap laba operasional dengan taraf kebenaran $95 \%$. Hasil penelitian tersebut sesuai dengan penelitian terdahulu dari Fitri, Shella (2013) yang membuktikan hasil penelitian, fee based income berpengaruh terhadap ROA dimana besarnya pengaruh fee based income sebesar $65,9 \%$ dan sisanya sebesar $34,1 \%$ dipengaruhi faktor lain yang tidak diteliti. Pada perbankan BUMN terdapat hubungan yang sangat kuat dan memiliki hubungan positif antara fee based income dan ROA.

Sedangkan pendapatan valuta asing merupakan pendapatan yang diperoleh dari hasil neto perusahaan. Hasil penelitian menunjukkan bahwa koefisien (b2) pendapatan valuta asing atau devisa $=0,309$. Dari angka tersebut dapat diketahui bahwa terdapat pengaruh positif dana pendapatan valuta asing atau devisa $\left(\mathrm{X}_{2}\right)$ terhadap laba operasional $(\mathrm{Y})$ yang berarti dengan adanya kenaikan pendapatan valuta asing atau devisa akan diikuti oleh kenaikan laba operasional. Pendapatan valuta asing atau devisa $\left(\mathrm{X}_{2}\right)$ memiliki nilai statistik thitung sebesar 7,329 dimana hasil yang didapatkan lebih besar dari t tabel untuk sampel sebanyak 32 adalah (2.042) dengan nilai probabilitas $0,000<0,05$, maka dapat disimpulkan bahwa terdapat berpengaruh yang signifikan atau nyata pendapatan valuta asing atau devisa terhadap laba operasional dengan taraf kebenaran $95 \%$.

Sedangkan pendapatan lainnya diperoleh hasil bahwa koefisien (b3) pendapatan lainnya $=2,503$. Dari angka tersebut dapat diketahui bahwa terdapat pengaruh positif pendapatan lainnya $\left(\mathrm{X}_{3}\right)$ terhadap laba operasional $(\mathrm{Y})$ yang berarti dengan adanya kenaikan pendapatan lainnya akan diikuti oleh kenaikan laba operasional. Kemudian nilai t hitung sebesar 1,996 dimana hasil yang didapatkan lebih kecil dari t tabel $(1,693)$ dengan nilai probabilitas 0,056>0,05 maka dapat disimpulkan bahwa terdapat berpengaruh positif yang tidak signifikan. Hasil penelitian tersebut di atas merupakan hasil penelitian yang mampu menunjukkan pengaruh secara simultan antara variabel $\mathrm{X}_{1}, \mathrm{X}_{2}, \mathrm{X}_{3}$ terhadap variabel $\mathrm{Y}$. Berdasarkan tabel di atas maka didapatkan hasil dari uji statistik $\mathrm{f}$ didapatkan nilai statistikf hitung 43,268 dimana hasil ini lebih besar dari $\mathrm{F}$ tabel pada $\mathrm{n}$ sebesar 32 didapatkan $(1,84)$ sehingga Ho ditolak yang mana dapat disimpulkan bahwa pendapatan komisi, provisi dan fee; pendapatan valuta asing atau devisa; dan pendapatan lainnya secara simultan atau bersama-sama berpengaruh signifikan terhadap laba operasional. Sedangkan pengaruhnya diperoleh kesimpulan bahwa Nilai $\mathrm{R}$ Square $=0,832$ menunjukkan bahwa variabel laba operasional (Y) dipengaruhi atau dapat dijelaskan oleh pendapatan komisi, provisi dan fee; pendapatan valuta asing atau devisa; dan pendapatan lainnya $\left(\mathrm{X}_{1,2,3}\right)$ mempengaruhi laba operasional sebesar $83,2 \%$, dan sisanya $16,8 \%$ dipengaruhi oleh faktor lain yang tidak dihitung dalam penelitian ini.

\section{KESIMPULAN DAN SARAN}

Kesimpulan penelitian ini adalah: (1) Penelitian ini bertujuan untuk menguji pengaruh Fee Based Income Terhadap Laba Operasional dari Bank Umum Milik Negara ( BUMN ) yang terdaftar di Bursa Efek Indonesia (BEI) periode 2007-2014; (2) Analisis data dilakukan dengan menggunakan regresi linier berganda; (3) Pendapatan komisi, provisi dan fee $\left(\mathrm{X}_{1}\right)$ berpengaruh positif dan signifikan terhadap laba operasional (Y) yang berarti dengan adanya kenaikan pendapatan komisi, provisi dan fee akan diikuti oleh peningkatan laba operasional; (4) Pendapatan valuta asing atau devisa $\left(\mathrm{X}_{2}\right)$ berpengaruh positif dan signifikan terhadap laba operasional (Y) yang berarti dengan adanya kenaikan pendapatan valuta asing atau devisa akan diikuti oleh peningkatan laba operasional; (5) Pendapatan lainnya $\left(\mathrm{X}_{3}\right)$ berpengaruh positif namun tidak signifikan terhadap laba operasional (Y) yang berarti dengan adanya kenaikan pendapatan lainnya akan diikuti oleh peningkatan laba operasional namun kenaikan tersebut bersifat tidak konsisten dan bisa berubah-ubah; dan (6) Secara simultan pendapatan komisi, provisi dan fee, Pendapatan valuta asing atau devisa, pendapatan lainnya $(\mathrm{X} 1,2,3)$ 


\section{Buletin Ekonomi}

mempengaruhi laba operasional sebesar $83,2 \%$, dan sisanya $16,8 \%$ dipengaruhi oleh faktor lain yang tidak dihitung dalam penelitian ini.

Saran yang dapat diberikan antara lain: (1) Penelitian ini belum dapat membuktikan pengaruh yang signifikan pendapatan lainnya terhadap laba operasional diharapkan bagi peneliti lain menguji kembali variabel ini dengan objek pada perusahaan lainnya; (2) Periode penelitian yang digunakan dalam penelitian ini relatif pendek yaitu dari tahun 2007 sampai dengan 2014, penelitian selanjutnya diharapkan dapat memperpanjang periode penelitian; (3) Penelitian ini hanya menggunakan jenis perusahaan dari sektor sektor perbankan BUMN, penelitian selanjutnya disarankan untuk mengambil sampel dari jenis industri yang lain yang lebih besar; dan (4) Bagi investor diharapkan mempertimbangkan Pendapatan Komisi, provisi dan fee, Pendapatan valuta Asing atau devisa sebagai evaluasi untuk mengambil keputusan dalam membeli saham karena berpengaruh terhadap pendapatan operasional..

\section{DAFTAR PUSTAKA}

Dajan Anto. 1996. Pengantar Metode Statistik Jilid II. Jakarta: Penerbit PT Pustaka LP3ES.

Dendawijaya, Lukman. (2005). Manajemen Perbankan. Jakarta: Ghalia Indonesia.

Dendawijaya, Lukman. (2009). Manajemen Perbankan. Jakarta: Ghalia Indonesia.

Djumhana. (1996). Hukum Perbankan di Indonesia.

Http://dikung .blogspot.com/2011/03/jasa jasa bank fee based income

Http://elib.unikom.ac.id/file/disk/131/jbptunikompp

Http://perdanayudha.wordpress.com/2011/03/08/bank/

Kasmir. (2008). Pemasaran Bank. Jakarta: PT Raja Grafindo.

Kasmir. (2012). Dasar-dasar perbankan. Jakarta: PT Raja Grafindo Persada.

Kasmir. (2012). Bank dan Lembaga Keuangan Lainnya. Jakarta: PT Raja Grafindo.

Lapoliwa, N. dkk. (2007). Akuntansi Perbankan. Jakarta: Institusi Bankir Indonesia.

Miftakhul Jannah (2013)“Pengaruh Penyaluran Kredit Usaha Mikro Kecil Menengah danPendapatan Operasional Terhadap Laba Operasional"

Nita Nur Astri (2014) "Pengaruh fee based income terhadap profitabilitas" pada Bank Umum Swasta Nasional Devisa yang terdapat di BEI

Shella Fitri (2013) "Pengaruh fee based income terhadap tingkat ROA" pada Bank BUMN yang terdaftar di BEI

Stice, stice dan Skousen (2004).

Sugiyono. (2012). Statistika Untuk Penelitian. Bandung: Alfabeta.

Sugiyono. (2010). Metodelogi Penilitian. Bandung: Alfabeta.

Taswan. (2006). Manajemen Perbankan. Yogyakarta: UPP STIM YKPN.

Undang-undang Perbankan. (2009). UU No. 10 th.1998. Jakarta. Sinar Diagrama.

Wild, Subramanyam, dan Halsey. (2005) 


\section{Buletin Ekonomi}

\section{Lampiran}

Tabel Penelitian Terdahulu

\begin{tabular}{|c|c|c|c|}
\hline Peneliti dan Judul & Variabel & Metode Analisis & Hasil Penelitian \\
\hline $\begin{array}{l}\text { Fitri (2013) } \\
\text { Pengaruh Fee Based } \\
\text { Income terhadap } \\
\text { ROA pada bank } \\
\text { BUMN yang } \\
\text { terdaftar di BEI }\end{array}$ & $\begin{array}{l}\mathrm{X}=\text { fee based } \\
\text { income } \\
\mathrm{Y}=\text { return on } \\
\text { Asset }\end{array}$ & $\begin{array}{l}\text { Studi empiris dengan } \\
\text { pendekatan nalisis } \\
\text { deskriptif verifikatif. } \\
\text { Penelitian dengan } \\
\text { menggunakan metode } \\
\text { verifikatif merupakan } \\
\text { analisis model dan } \\
\text { pembuktian yang berguna } \\
\text { untuk mencari kebenaran } \\
\text { dari hipotesis yang } \\
\text { diajukan }\end{array}$ & $\begin{array}{l}\text { Hasil penelitian, fee based income } \\
\text { berpengaruh terhadap ROA dimana } \\
\text { besarnya pengaruh fee based income } \\
65,9 \% \text { dan sisanya sebesar } 34,1 \% \\
\text { dipengaruhi faktor lain. Pada } \\
\text { perbankan BUMN terdapat hubungan } \\
\text { yang sangat kuat dan positif antara } \\
\text { fee based income dan ROA }\end{array}$ \\
\hline $\begin{array}{l}\text { Indrawati (2013) } \\
\text { Kegiatan Pelaksanan } \\
\text { Fee Based Income } \\
\text { dari Jasa Safe } \\
\text { Deposit Box pada } \\
\text { PT. Bank Negara } \\
\text { Indonesia }\end{array}$ & & $\begin{array}{l}\text { Dengan jenis pendekatan } \\
\text { studi kasus metode } \\
\text { penelitian menggunakan } \\
\text { pendekatan deskripfit } \\
\text { asosiatif dengan jenis } \\
\text { pendekatan studi kasus } \\
\text { yaitu dengan melihat } \\
\text { fenomena permasalahan } \\
\text { yang ada di perusahaan } \\
\text { yang kan diteliti }\end{array}$ & $\begin{array}{l}\text { Hasil penelitian, fee based income } \\
\text { berupa pelaksanaan jsa safe deposit } \\
\text { box mampu meningkatkan } \\
\text { pendapatan non operasional pada } \\
\text { Bank Negara Indonesia }\end{array}$ \\
\hline $\begin{array}{l}\text { Astri (2014) } \\
\text { Pengaruh fee based } \\
\text { income terhadap } \\
\text { profitabilitas pada } \\
\text { Bank Umum Swasta } \\
\text { Nasional Devisa } \\
\text { yang terdaftar di BEI }\end{array}$ & $\begin{array}{l}\mathrm{X}=\text { fee based } \\
\text { income } \\
\mathrm{Y}= \\
\text { profitabilitas }\end{array}$ & $\begin{array}{l}\text { Dengan jenis pendekatan } \\
\text { studi kasus metode } \\
\text { penelitian menggunakan } \\
\text { pendekatan deskripfit } \\
\text { asosiatif dengan jenis } \\
\text { pendekatan studi kasus } \\
\text { yaitu dengan melihat } \\
\text { fenomena permasalahan } \\
\text { yang ada di perusahaan } \\
\text { yang kan diteliti }\end{array}$ & $\begin{array}{l}\text { Hasil penelitian, fee based income } \\
\text { berpengaruh terhadap profitabilitas } \\
\text { dimana besarnya pengaruh fee based } \\
\text { income } 85,56 \% \text { dan sisanya sebesar } \\
14,44 \% \text { dipengaruhi faktor lain. Hal } \\
\text { tersebut menunjukkan ketika terjadi } \\
\text { peningkatan fee based income makan } \\
\text { akan berdampak pula pada kenaikan } \\
\text { profitabilitas }\end{array}$ \\
\hline $\begin{array}{l}\text { Pertiwi (2015) } \\
\text { Pengaruh fee based } \\
\text { income terhadap } \\
\text { profitabilitas pada } \\
\text { Bank BUMN yang } \\
\text { terdaftar di BEI }\end{array}$ & $\begin{array}{l}\mathrm{X}=\text { fee based } \\
\text { income } \\
\mathrm{Y}= \\
\text { profitabilitas }\end{array}$ & $\begin{array}{l}\text { Dengan jenis pendekatan } \\
\text { studi kasusMetode } \\
\text { penelitian menggunakan } \\
\text { pendekatan deskripfit } \\
\text { asosiatif dengan jenis } \\
\text { pendekatan studi kasus } \\
\text { yaitu dengan melihat } \\
\text { fenomena permasalahan } \\
\text { yang ada di perusahaan } \\
\text { yang kan diteliti }\end{array}$ & $\begin{array}{l}\text { Hasil penelitian, fee based income } \\
\text { berpengaruh terhadap profitabilitas } \\
\text { Secara simultan pendapatan komisi, } \\
\text { provisi dan fee, Pendapatan valuta } \\
\text { asing atau devisa, pendapatan lainnya } \\
\text { (X1,2,3) mempengaruhi laba } \\
\text { operasional sebesar 83,2\%, dan } \\
\text { sisanya 16,8\% dipengaruhi oleh } \\
\text { faktor lain yang tidak dihitung dalam } \\
\text { penelitian ini. }\end{array}$ \\
\hline
\end{tabular}

